\title{
BARD1 wt Allele
}

National Cancer Institute

\section{Source}

National Cancer Institute. BARD1 wt Allele. NCI Thesaurus. Code C49396.

Human BARD1 wild-type allele is located in the vicinity of 2q34-q35 and is approximately $1 \mathrm{~kb}$ in length. This allele, which encodes BRCA1-associated RING domain protein 1, plays a role in tumor suppression, apoptosis and cellular growth. 